\title{
A mutabilidade do regime de bens entre cônjuges no Código Civil de 2002
}

\section{Resumo}

A possibilidade de alterar o regime de bens no casamento é uma das mais salutares inovações do direito patrimonial de família no Código Civil de 2002 (art. 1.639 § 2º). A aplicação intertemporal da mutabilidade e os requisitos do pedido são tratados neste artigo que, antes, analisa a natureza jurídica do casamento e as disposições gerais sobre os regimes de bens.

\section{Abstract}

The possibility to change the marriage patrimony regimen is one of the most salutary innovations concerning family patrimonial laws in the Civil Code of 2002 (art. $1.639 \$ 2^{\circ}$ ). The conflict of laws in time relating to such possibility and the petition requirements are dealt with in this article which analyses, beforehand, the marriage legal nature and the general rules regarding its patrimony regimen.

\section{1 - Natureza jurídica do casamento}

$\mathrm{O}$ regime de bens entre cônjuges inaugura o direito patrimonial de família, distinguindo-se do direito pessoal de família, classificação inovadora no Direito brasileiro, mas já tradicional na Doutrina francesa.

Além do regime de bens entre cônjuges, fazem parte do Direito patrimonial de família o regime de bens entre companheiros, o usufruto e a administração dos bens de filhos menores, os alimentos e o bem de família.

Antes de analisar o regime de bens no casamento, é oportuno o estudo de aspectos fundamentais do casamento, notadamente conceito e natureza jurídica.

O Direito moderno utiliza os dois conceitos romanos, o de Modestino e o de Ulpiano, das Institutas.

No Corpus Juris Civilis, o conceito é atribuído a Modestino. Digesto 23, 2, 1:

"Núpcias são a união do homem e da mulher e o consórcio de toda a vida, a comunicação do direito divino e humano".

Nas Institutas de Ulpiano, o texto está em I, 9, 1: "Núpcias ou matrimônio são a união do homem e da mulher implicando uma indivisível comunhão de vida".

Quanto à natureza jurídica do casamento há duas teses principais: a que sustenta ser ele uma instituição e a que o caracteriza como contrato.

Segundo a ótica institucionalista, o casamento é uma instituição social, refletindo uma situação jurídica que surge da vontade dos contraentes, mas cujas normas, efeitos e forma encontram-se preestabelecidos pela lei.

Uma vez que houve adesão ao "estado matrimonial", a vontade dos nubentes não é bastante, sendo automáticos os efeitos da instituição por serem de ordem pública ou cogentes.

O estado matrimonial é um estatuto imperativo com regras preestabelecidas, ao qual os

\footnotetext{
* Professora Associada da Faculdade de Direito da Universidade de São Paulo (doutora e livre-docente). Coordenadora e Professora do curso de Direito das Faculdades Integradas "Campos Salles".

${ }^{1}$ Nuptiae sunt conjunctio maris et feminae et consortium omnis vitae, divini et humani juris communicatio. GIORDANI, Mário Curtis. O Código civil à luz do Direito Romano. Direito de Família. Rio de Janeiro: Lumen Juris, 1996.

${ }^{2}$ Nuptiae autem sive matrimonium est viri et mulieris conjunctio individuam consuetudinem vitae continens. GIORDANI, Mário Curtis, op.cit.
} 
nubentes simplesmente emprestam sua adesão, sem liberdade de adotar outras normas.

Rubens Limongi França ${ }^{3}$, Maria Helena Diniz, Washington de Barros Monteiro ${ }^{4}$ e muitos outros autores defendem que o casamento é uma instituição de Direito privado.

Calogero Gangi conceitua casamento como a união de um homem e de uma mulher para formar uma família legítima.

"É uma união estável, duradoura por toda a vida dos cônjuges, formada nas formas e segundo as normas estabelecidas pela lei, para a satisfação de suas necessidades sexuais, para a comunhão de sua vida, para a recíproca assistência, bem como para a procriação, criação e a educação da prole". 5

Anote-se o conceito de Lafayette, para quem o casamento é instituição, diferindo do contrato com o qual tem apenas, como ponto de contato, o de exigir a manifestação do consentimento das partes para a formação:

"Casamento é um ato solene pelo qual duas pessoas de sexo diferente se unem para sempre, sob promessa recíproca de fidelidade no amor e da mais estreita comunhão de vida". 6

Entre nós a concepção institucionalista teve seu mais ardoroso defensor em Rubens Limongi França que a ela dedica exaustivo estudo tanto em ensaio como no Manual de Direito Civil, volume 2, tomo 1 .

Para o autor, casamento é "uma instituição, com caracteres próprios que nasce de um ato jurídico de feição complexa".?

E, como ato jurídico, é "o acordo de vontades de um homem e de uma mulher, no sentido de se unirem permanentemente, com o escopo do auxílio mútuo material, moral, espiritual e afetivo - bem assim da perpetuação da espécie, através da procriação e educação da prole".

Como vínculo, é "a própria união, consentida e levada a efeito com aquelas finalidades".

Como sociedade, "é o conjunto de direitos e obrigações recíprocos, oriundos da adesão dos cônjuges à idéia-finalidade, ínsita à instituição da família".

Como estado, "é o modo de ser, jurídico e de fato, de caráter indissolúvel ou permanente que advém do inicial acordo de vontades dos cônjuges".

A concepção contratualista origina-se do Direito Canônico que, no Cânone 1.012, alude a "contrato matrimonial". Passou para o Código Civil Francês de 1804, influenciou a Escola Exegética do século XIX e permanece na doutrina civilista que sustenta ter o casamento natureza jurídica de contrato especial ou sui generis (contrato de direito de família).

Entre seus defensores, citamos, entre outros, Espínola ${ }^{9}$, Orlando Gomes ${ }^{10}$ e Silvio Rodrigues ${ }^{11}$. Parece ser também a opinião de Caio Mário da Silva Pereira ${ }^{12}$ ao analisar os diversos argumentos de uma e outra teoria, às quais acresce a que sustenta ser o casamento, ato complexo - defendida por Vassalli - e a que o qualifica como atocondição (Duguit).

Clóvis Bevilaqua assim conceitua casamento, utilizando expressamente a palavra "contrato":

"Casamento é um contrato bilateral e solene pelo qual um homem e uma mulher se unem indissoluvelmente, legitimando por ele suas relações sexuais; estabelecendo a mais estreita comunhão de vida e de in-

\footnotetext{
${ }^{3}$ FRANÇA, Rubens Limongi. Do matrimônio como fato jurídico. Revista dos Tribunais, São Paulo. 389:21, n. 6.

${ }^{4}$ MONTEIRO, Washington de Barros. Curso de Direito Civil Brasileiro: Direito de Família. 36.ed. São Paulo: Saraiva, 2001, p. 13.

${ }^{5}$ GANGI, Calogero. Il Matrimonio. Terza edizione. Milano: Giuffrè-Editore, 1953. p. 5-6.

${ }^{6}$ PEREIRA, Lafayette Rodrigues. Direitos de Família. Anotações e adaptações ao Código Civil por José Bonifácio de Andrada e Silva. Rio de Janeiro: Virgilio Maia, 1918. Citação no parágrafo 8ํㅜ, p. 30.

${ }^{7}$ FRANÇA, Rubens Limongi. Manual de Direito Civil. v. 2, tomo 1. São Paulo: Revista dos Tribunais, 1972, p. 134-5.

${ }^{8}$ FRANÇA, Rubens Limongi. Manual de Direito Civil. v. 2, tomo 1. São Paulo: Revista dos Tribunais, 1972, p. 121-22. Vide também, do mesmo autor, o`ensaio Do matrimônio como fato jurídico. Revista dos Tribunais, 1968.

${ }^{9}$ ESPÍNOLA, Eduardo. A Família no Direito Civil brasileiro. Rio de Janeiro: Gazeta Judiciária, 1957. n.12.

${ }^{10}$ GOMES, Orlando. Direito de Família. 11.ed. Atualizada por Humberto Teodoro Júnior. Rio de Janeiro: Forense, 1999, p. 58-60.

${ }^{11}$ RODRIGUES, Silvio. Direito civil: Direito de Família. 27.ed. São Paulo: Saraiva, 2002, p. 19.

${ }^{12}$ PEREIRA, Caio Mário da Silva. Instituições de Direito Civil. Direito de Família. 11. ed. Rio de Janeiro: Forense. v. 6, p. 36.
} 
teresses e comprometendo-se a criar e educar a prole que de ambos nascer". ${ }^{13}$

Entre os autores da atualidade, um dos mais entusiastas defensores da natureza contratual do casamento é Alvaro Villaça Azevedo, para quem casamento é "um contrato solene, regulado por normas de ordem pública, no âmbito do Direito de Família, pelo qual um homem e uma mulher, criando, com ele, sua sociedade conjugal, submetem-se a um complexo de direitos e de deveres, entre si e entre eles e seus filhos, de ordem pessoal e patrimonial". ${ }^{14}$

Entre os vários argumentos que sustentam a teoria contrária, a institucionalista, cite-se o invocado por uma de suas adeptas, Maria Helena Diniz, que enfatiza ter o contrato, no acordo de vontade dos contraentes, seu principal elemento, mas a vontade dos nubentes não pode constituí-lo.

Requer necessariamente a intervenção da autoridade eclesiástica ou civil para sancionar e homologar tal acordo.

Álvaro Villaça Azevedo contesta esse argumento aduzindo que a vontade dos nubentes selase com a intervenção do juiz de casamento que comparece unicamente para atender à solenidade do ato e livrá-lo de possíveis imperfeições. Essa atuação oficial não é constitutiva do contrato matrimonial de Direito de Família, mas meramente declaratória de sua existência. Também faz a mesma afirmação Eduardo Espínola. ${ }^{15}$

Para o autor, "a vida contratual surge não no momento da celebração, mas da manifestação da vontade dos nubentes. Com esta nida-se a formação contratual, que permanece nascitura até que a celebração, retroagindo a ela, aperfeiçoe o contrato de casamento". ${ }^{16}$

Outro argumento oposto pelos que perfilham a teoria institucionalista repousa em que no contrato as partes estabefecem livremente o conteúdo.

A mim não convence esse argumento, em que pese a respeitabilidade dos que o sustentam.

O Direito de Família é informado por normas de ordem pública, por ser um direito protetivo, como tantos outros que tutelam a parte mais fraca, entre os quais cito o Direito do Consumidor e o Direito de Autor.

Lembro que, quanto ao conteúdo, no contrato de adesão não há a mesma liberdade que no contrato paritário.

O terceiro argumento liga-se estreitamente ao segundo, pois funda-se em que as normas que informam o casamento são de ordem pública. Não há dissenso quanto a essa constatação, mas não me parece hábil para afastar a natureza contratual do casamento, pois vários contratos de Direito Civil - como o de locação, de seguro, de Direito Autoral e de Direito do Consumidor são informados por normas de ordem pública.

Este argumento contrário à natureza contratual do casamento também foi contestado por Eduardo Espínola, que já afirmara que "nos próprios contratos de indiscutivel natureza privada se encontram disposições de ordem pública, que restringem a autonomia da vontade". ${ }^{17}$

$\mathrm{O}$ quarto argumento que contestaria a natureza contratual repousa em que o casamento não pode ser dissolvido por mútuo consenso ou pelo distrato.

Por mútuo consenso, pode o casamento ser dissolvido por meio da separação consensual ou por divórcio direto.

Por tais razões, incluo-me entre os adeptos da teoria contratualista do casamento que terá relevância maior no direito patrimonial, o regime de bens, notadamente o que tiver sido escolhido pelos interessados.

Enfatize-se a inovação salutar e já tardia do Código Civil vigente quanto à possibilidade de alteração do regime de bens, o que prestigia ainda

\footnotetext{
${ }^{13}$ BEVILAQUA, Clóvis. Direito de Família. 5.ed. Rio de Janeiro: Freitas Bastos, 1933. parágrafo 6º, p. 36.

${ }^{14}$ AZEVEDO, Álvaro Villaça. Contrato de Casamento, sua extinção e renúncia de alimentos na separação consensual. In: Estudos em homenagem a Washington de Barros Monteiro. São Paulo: Saraiva, 1982.

${ }^{15}$ ESPÍNOLA, op. cit., p. 49.

${ }^{16}$ AZEVEDO, op. cit. p. 47.

${ }^{17}$ ESPÍNOLA, op. cit., p. 49 e nota 15.
} 
mais a tese contratualista, por fundar-se na vontade das partes, ainda que deva ser justificada.

É necessário frisar tratar-se de contrato de Direito de Família, expressão já utilizada por Eduardo Espínola, contrato diferenciado ou sui generis, informado por normas de ordem pública próprias desse ramo especial do Direito Civil.

\section{2 - Do regime de bens}

Com o casamento começa a vigorar o regime de bens, no mais das vezes de livre escolha dos nubentes e, de modo excepcional, por razões de ordem pública, impostas pelo legislador. Os regimes da primeira espécie denominam-se regime convencional de bens ao passo que os segundos, regime legal de bens.

O regime de bens é conseqüência necessária do casamento, conforme sustentado por François Terré e Philippe Simler ${ }^{18}$, para quem "os efeitos pessoais da união conjugal não podem ser totalmente dissociados de seus efeitos pecuniários e esses não podem ser análogos aos que resultam de qualquer associação, sociedade ou grupo constituído entre pessoas não casadas, quaisquer que sejam os sentimentos que as animem".

No mesmo sentido, cite-se Arnold Wald que bem adverte quanto à impropriedade da incidência de regras gerais do direito das obrigações a um homem e a uma mulher ligados pelo casamento. A eles não se poderia aplicar, por exemplo, as regras do enriquecimento sem causa, da gestão de negócios, do comodato e do mútuo, sob pena de gerar-se a instabilidade na vida privada das pessoas, desvirtuando os fins do casamento.

Com oportunidade observa que a sociedade conjugal, por süas peculiaridades, requer regulamentação especial.

Acrescento que a mesma razão se aplica ao regime de bens entre companheiros, já que reconhecida como família, a união estável, desde o advento da Constituição Federal.

A diferença entre a sociedade conjugal e as demais sociedades já foi objeto de estudos de vários autores, os quais apontam, como característica diferenciadora, a falta do objetivo de lucro entre aquela e estas. Em que pese opinião minoritária em contrário, na comunhão conjugal os cônjuges não a criam visando lucro, faltando a affectio societatis.

A especificidade do regime de bens no casamento decorre, sem dúvida, da natureza especial e diferenciada da sociedade conjugal que não se equipara com as sociedades comuns, entre pessoas não unidas por relações de afeto como tônica e, secundariamente, por razões patrimoniais.

Ao menos, em regra, ou como deveria ser para casamentos e uniões estáveis.

A Constituição Federal enfatizou a dignidade da pessoa humana, prestigiando, destarte, o direito pessoal de família, com a preocupação de centralizar-se na pessoa, como um fim em si mesmo. Esse norte reflete-se em todo o Direito Civil, passando pela relevância dada aos direitos da personalidade - artigos 11 a 21 - pelo princípio da boa-fé nos contratos, pela responsabilidade civil que caminha da subjetividade para a objetividade, pela função social da propriedade e do contrato, pela redução do poder restritivo de direitos, do testador. ${ }^{19}$

A família é ambiente de grande relevância, para que seu membro possa realizar-se e para tanto é necessário que se vislumbre o direito pessoal de família com a tônica na pessoa natural, sob a ótica dos direitos da personalidade.

O direito patrimonial de família, do qual o regime de bens é parte expressiva, deve também ser analisado sob esse prisma, visando soluções mais equilibradas e solidárias nas várias questões

\footnotetext{
${ }^{18}$ TERRÉ, François; SIMLER, Philippe. Les régimes matrimoniaux. 3.ed. Paris: Dalloz, 2001. p.9.

${ }^{19}$ A respeito das diretrizes do novo Código Civil, consulte-se, de Miguel Reale, Visão geral do Projeto de Código civil. In: O Projeto do novo Código Civil. São Paulo: Saraiva, 1999, 1-22. Consulte-se, ainda, Visão geral do Código Civil. In: www.miguelreale.com.br.
} 
pecuniárias entre cônjuges, nem sempre tão claras na dicção abstrata da lei.

Pontes de Miranda assim define regime de bens:

"É o conjunto de regras, mais ou menos orgânico, que estabelece para certos bens, ou para os bens subjetivamente caracterizados, sistema de destinação e de efeito. Há regime de bens sujeito à Lei Torrens, de zonas militarmente vigiadas, das minas consideradas de imediata utilidade para a defesa nacional e de regime matrimonial de bens" ${ }^{20}$

Em sentido estrito, Clóvis Bevilaqua ${ }^{21}$ conceitua regime de bens no casamento como "o conjunto dos princípios jurídicos que regulam as relações econômicas entre os cônjuges".

Para Sílvio Rodrigues"2, "é o estatuto que regula os interesses patrimoniais durante o matrimônio".

Louvando-se em Roguin, Caio Mário da Silva Pereira $^{23}$ define o regime de bens entre cônjuges como o "conjunto de regras, determinando as relações pecuniárias que resultam do casamento".

Entre nós a natureza contratual do casamento é defendida por inúmeros autores, entre os quais Álvaro Villaça Azevedo, tese avalizada por mim, para quem o casamento tem a natureza contratual, com a especificidade de se tratar de contrato de Direito de Família, informado por muitas normas de ordem pública que, por isso, não comportam convenção em contrário. Outras, de natureza dispositiva, comportam-na e podem ser objeto de pacto antenupcial. A mutabilidade do regime de bens, admitida pelo novo Código prestigia a natureza contratual do casamento, não descaracterizada pela necessidade de motivação do pedido e deferimento judicial.

Ao tratar do regime de bens no casamento, José Lamartine Corrêa de Oliveira e Francisco José Ferreira Muniz advertem que dele decorre um conjunto de normas que disciplinam imperativamente a organização e o funcionamento econômico da vida do lar, e que se aplica de uma maneira idêntica a todos os casais, qualquer que seja o regime matrimonial a que estejam submetidos. (grifo nosso).

Invocam, como exemplos os artigos 233, 234, 240, 242, 243, 244, 245, 246, 247, 248, 251 e 254 do Código Civil de 1916.

Essas normas gerais e inderrogáveis formam o que se denomina, nas doutrinas francesa e belga, de regime matrimonial primário, estatuto imperativo de base, regime primário imperativo ou estatuto patrimonial de base. (grifo nosso).

Constituem um corpo de regras distintas e, em princípio, independentes das normas que constituem os regimes matrimoniais, propriamente ditos, ou regimes matrimoniais secundários (grifo nosso) o que não exclui algumas influências recíprocas. ${ }^{24}$

Não são nítidos os limites entre o regime primário e o regime de bens, propriamente dito.

\section{3 - Direito intertemporal e regime de bens}

O Código Civil de 2002, como o de 1916, estatui regras gerais que se aplicam aos regimes típicos previstos e ao não típico, aqui admitido para argumentar.

Entre as regras gerais que constituem o regime primário imperativo cito, no Código vigente, as disposições gerais constantes nos artigos 1.639 a 1.652 , bem como as relativas ao pacto antenupcial (artigos 1.653 a 1.657).

Realmente, por sua natureza, conteúdo e objetivos, o casamento importa muitos efeitos econômicos, independentemente do regime de bens, como, por exemplo: a necessidade de contribuírem os cônjuges para o sustento do lar, para as despesas comuns, para atender os encargos da

\footnotetext{
${ }^{20}$ PONTES DE MIRANDA, Francisco Cavalcanti. Tratado de Direito de Família: Direito matrimonial. São Paulo: Max Limonad, 1947. v. 2 p. 127.

${ }^{21}$ BEVILAQUA, Clovis, op. cit. p. 184.

${ }^{22}$ RODRIGUES, Silvio, op. cit. p. 126.

${ }^{23}$ PEREIRA, Caio Mario da Silva, op. cit.p.118.

${ }^{24}$ OLIVEIRA, José Lamartine Correa de; MUNIZ, Francisco. Curso de Direito de Família. 3. ed. Curitiba: Juruá, 1999.
} 
família, inclusive manutenção da casa, compra das coisas necessárias à economia doméstica, para o sustento, guarda e educação dos filhos.

O alcance da regra de direito intertemporal consagrada no artigo 2.039 das disposições finais e transitórias do CC não deve ser interpretado literalmente, como pareceu a alguns:

"O regime de bens nos casamentos celebrados na vigência do Código Civil anterior, Lei no 3.071 , de $1^{\text {o }}$ de janeiro de 1916, é o por ele estabelecido".

Necessária a regra, pois, na vigência do Código revogado, havia um regime hoje não mais existente, o dotal; o regime legal de bens era o da comunhão universal, até o advento da Lei do Divórcio, Lei 6.515 , de 26 de dezembro de 1977. O regime dotal reger-se-á pelo Código de 1916, bem como os casados sob o regime legal da comunhão universal de bens continuarão a ter sua vida patrimonial por ele regida, não obstante o regime legal do novo Código seja o da comunhão parcial. ${ }^{25}$

A mim parece que a regra de direito intertemporal do artigo 2.039 do Código vigente segundo a qual casamentos celebrados na vigência do CC de 1916 obedeçam ao que ele prevê não se refere às regras gerais, nem aos regimes secundários, os regimes específicos de bens, típicos ou não típicos, para aqueles que o admitem.

Se houver incompatibilidade entre o disposto no Código revogado e o atual, prevalece o novo para atos praticados depois do início de sua vigência.

Atos e negócios jurídicos que ocorreram antes de 11 de janeiro de 2002 sujeitam-se aos ditames do Código de 1916, enquanto os que ocorreram depois dessa data submetem-se ao novo Código. Acresça-se que, aceita a natureza contratual do casamento - contrato especial de Direito de Família - é ele contrato de prestação contínua do qual derivam atos e negócios jurídicos celebrados na vigência do Código de 1916 e, outros, na vigência do Código de 2002.
Não se há de confundir efeito imediato da lei com efeito retroativo, vedado pela Constituição Federal, em tradição do direito brasileiro.

Por exemplo: estabelece o artigo 235 do Código revogado que o marido não pode, sem o consentimento da mulher, qualquer que seja o regime de bens, prestar fiança (inciso III), sendo omisso quanto ao aval.

No novo Código, o aval é mencionado expressamente no artigo correspondente ao 235 , ou seja, artigo 1.647 , inciso III.

Assim, na vigência do novo Código, prevalece o que ele estabelecer quanto à proibição de o marido prestar aval sem o consentimento da mulher, mesmo quanto a casamentos celebrados na vigência do Código de 1916.

mesmo raciocínio se aplica às obrigações provenientes de ato ilícito, que o Código revogado considera incomunicável no regime da comunhão parcial, dela excluindo-as (inciso II do artigo 270), sem fazer qualquer ressalva quanto ao requisito de não ter havido proveito para o casal, como o faz o inciso IV do artigo 1.659 do Código de 2002.

Atos ilícitos praticados por um cônjuge, na vigência do Código atual, só não se comunicarão à meação do outro, se ficar provado que não houve proveito ao casal. Não seria admissível que, invocando "direito adquirido" decorrente da celebração do casamento na vigência do Código de 1916, pudesse o cônjuge beneficiar-se do proveito com o ato ilícito praticado pelo outro, sem que houvesse comunicação a sua meação.

Exemplifique-se, ainda, com a mudança do regime da separação de bens que, no novo Código admite a livre alienação de bens da propriedade de cada cônjuge (artigo 1.687) diferentemente do artigo 276 do Código de 1916 que exigia autorização do outro.

Se a alienação ocorre na vigência do Código de 2002, embora o casamento tenha sido celebrado sob o Código revogado, incide a lei atual,

\footnotetext{
${ }^{25}$ No mesmo sentido opina Gustavo Mônaco em Lei de Introdução. Disposições Transitórias. Direito Intertemporal. O Novo Código Civil - o que muda na vida do cidadão, realizado em Câmara dos Deputados. Centro de Documentação e Informação. Coordenação de Publicações. Brasília, 2003. p. 298-308, especialmente p. 306-7.
} 
dispensado o cônjuge da outorga marital ou uxória, conforme o caso.

Mesmo para os autores que pretendem haver "direito adquirido" quanto à regência pelo Código Civil de 1916, o vigente na data da celebração do casamento, haveria, quanto às regras gerais, ou estatuto primário, prevalência do Código vigente, o que alcançaria a possibilidade de alteração do regime de bens. ${ }^{26}$

Assim sendo, tanto para os que perfilham tal tese como para mim, que enfatizo a aplicação imediata da lei nova - o que não se confunde com retroatividade - a mutabilidade do regime de bens alcança os casamentos celebrados na vigência do Código de 1916, devendo os interessados requerer a mudança ao juiz, em pedido justificado, conforme parágrafo 2. do artigo 1.639. ${ }^{27}$ Uma vez deferida, vigorará a partir de então e esse novo regime obedecerá aos ditames do Código Civil ora em vigor.

Bens adquiridos antes do deferimento da mudança do regime, obedecem ao anteriormente estabelecido. Se são comuns, continuarão com tal natureza; se são particulares, continuarão a sê-lo.

Permito-me lembrar que, com o advento da Lei do divórcio, em dezembro de 1977 (Lei 6.515), a dissolução do vínculo conjugal foi reconhecida também aos que se casaram antes dela, não tendo havido polêmica relevante quanto a essa possibilidade, o que reforça o argumento no sentido de que as regras relativas ao regime primário de bens, regras gerais aplicáveis a todos eles, têm eficácia imediata, o que não se confunde com efeito retroativo.
As questões de direito intertemporal representarão um ponto a mais a discutir em cada caso concreto, devendo-se distinguir o efeito imediato e o efeito retroativo. Só este é vedado pela Constituição Federal, embora nem sempre sejam claros os limites de cada um, notadamente quando se trata de efeitos posteriores de atos ou negócios jurídicos celebrados na vigência da lei anterior.

Remeto-me novamente à obra ímpar de Rubens Limongi França, representada por duas monografias com sólida base teórica, louvada em pesquisa profunda, bem como à terceira obra, em que faz análise crítica da jurisprudência. ${ }^{28}$

Euclides de Oliveira também defende a aplicabilidade das regras gerais dos regimes de bens, entre as quais a mutabilidade, aos casamentos celebrados antes do Código Civil de 2002.

No artigo Alteração do regime de bens no casamento, ${ }^{29} \mathrm{o}$ autor analisa duas sentenças judiciais de São Paulo que acolheram a tese por mim e por ele defendidas, ou seja, a possibilidade de mudança do regime de bens aos casamentos realizados na vigência do Código de 1916.

A primeira sentença foi proferida no processo nº 000.03.026973-3, da 12 a Vara de Família e Sucessões do Foro Central, o Juiz JOÃO BATISTA SILVÉRIO DA SILVA. A segunda, foi prolatada pelo juiz Francisco Aguilar Cortez no processo n⿳0 000.03.013779-9, da $1^{\text {a }}$ Vara de Família e Sucessões do Foro Central de São Paulo.

Tanto uma como outra louvam-se em bons argumentos quase todos, além de outros, por mim considerados no teor do comentário ao $§ 2^{\mathrm{o}}$ do artigo 1.639 do Código Civil. ${ }^{30}$

\footnotetext{
${ }^{26}$ Neste sentido, Luiz Felipe Brasil Santos. In: A mutabilidade dos regimes de bens. www.migalhas.com.br/todos os autores/todos os artigos. Disponívël também em www.ibdfam.com.br. Acesso em agosto de 2004.

${ }^{27}$ Segundo o art. 2.039 do Código Civil: "o regime de bens nos casamentos celebrados na vigência do Código Civil anterior, Lei n. 3.071, de 1ํ de janeiro de 1916, é o por ele estabelecido".

${ }^{28}$ FRANÇA, Rubens Limongi. Direito Intertemporal Brasileiro. 2.ed. São Paulo: Revista dos Tribunais, 1968. . A irretroatividade das leis e o direito adquirido. 6. ed. São Paulo: Saraiva, 2000. - Jurisprudência da irretroatividade e do direito adquirido. São Paulo: Revista dos Tribunais, 1982.

${ }^{29}$ DELGADO, Mario Luiz; FIGUEIREDO, Jones (Coord.) Alteração do regime de bens no casamento. In: Novo Código Civil. Questões controvertidas. São Paulo: Métodos, 2003, p. 389-404.

${ }^{30}$ CHINELATO, Silmara Juny. Comentários ao Código Civil. Direito de Família. São Paulo: Saraiva, 2004. v. 18, p. 37-50. Consultese comentário ao art. 1.667.
} 
Na mesma obra, merece indicação o artigo de Mário Luiz Delgado. ${ }^{31} \mathrm{O}$ autor sustenta, igualmente, a tese da aplicabilidade do regime da alteração do regime de bens aos casamentos celebrados na vigência do Código Civil de 1916, enfatizando na página 506:

"Por ora, manifestamos posição no sentido de que as disposições gerais sobre regime de bens previstas nos artigos 1.639 a 1.657 seriam aplicáveis a todos os casos, inclusive para os casamentos celebrados anteriormente a 11 de janeiro de 2.003".

$\mathrm{Na} 3^{\text {a }}$ Vara de Família e Sucessões de Porto Alegre, Proc. no 00113454988, a juíza Jucelana Lurdes Pereira dos Santos deferiu em 16 de jutho de 2004 o pedido de um casal de empresários que queria abrir filial da empresa em que são sócios, pedido obstado na esfera administrativa, pelo fato de o novo Código Civil não mais permitir sociedade entre cônjuges casados pelo regime da comunhão universal de bens, conforme artigo 977, dispositivo criticado por mim em Comentários ao Código Civil. Parte Especial. Direito de Família. ${ }^{32}$

Registro acórdão do Tribunal de Justiça do Rio Grande do Sul que acolhe a tese da aplicação da regra da mutabilidade do regime de bens no casamento, aos celebrados na vigência do Código anterior.

Relatado pelo Desembargador Sérgio Fernando de Vasconcellos, foi julgado em 22 de outubro de 2003 na apelação cível n 70006709950 da sétima Câmara, por votação unânime, da qual participaram os Desembargadores José Carlos Teixeira Giorgis, Presidente, e Luiz Felipe Brasil Santos.

Da ementa destaco as partes que interessam para este estudo:

"2. A pretensão deduzida pelos recorrentes que pretendem adotar oregime da comunhão universal de bens é possivivel juridicamente, consoante estabelece o art. $1.639 \S 2^{\circ}$ do NCCB e as razões postas pelas partes são bastante ponderáveis, constituindo o pedido moti- vado de que trata a lei e que foi formulado pelo casal. Assim, cabe ao julgador a quo apreciar o mérito do pedido e, sendo deferida a alteração de regime, desnecessário será lavrar escritura pública, sendo bastante a expedição do competente mandado judicial. O pacto antenupcial é ato notarial, a alteração do regime matrimonial é ato judicial. 3. A alteração do regime de bens pode ser promovida a qualquer tempo, de regra com efeito ex tunc, ressalvados direitos de terceiros. Inteligência do artigo 2.039 do NCBB. 4. É possível alterar regime de bens de casamentos anteriores à vigência do Código Civil de 2002. Recurso provido. Segredo de Justiça". ${ }^{33}$

Embora concorde com a tese principal - incidência da regra da mutabilidade aos casamentos celebrados antes do Código Civil de 2002 - ressalvo meu entendimento contrário ao efeito retroativo da decisão judicial. No meu modo de ver o novo regime de bens incide apenas a partir da sentença judicial que deferiu o pedido dos interessados, tendo efeito imediato, permanecendo o regime anteriormente adotado quanto aos bens adquiridos sob sua vigência.

Há efeito imediato da lei o que não se confunde com retroatividade.

Não houve intenção do legislador em provocar a retroatividade do novo regime - o que deflui inequivocamente do artigo 2.039 das Disposições Transitórias do Código Civil de 2002 o que se harmoniza com a regra da irretroatividade consagrada o inciso XXXVI do artigo 5o da Constituição Federal e no artigo 6ํㅡㄹ Lei de Introdução do Código Civil, invocando-se , ainda, a experiência de outros países que já adotaram a mutabilidade de regimes de bens.

Os acórdãos mais recentes do Tribunal de Justiça de São Paulo admitem a aplicação do Código Civil de 2002, quanto a mutabilidade do regime de bens, aos casamentos celebrados antes de sua vigência. Entre eles anoto o lavrado na Apelação Cível no 302.914-4/8, Relator Desembargador An-

\footnotetext{
${ }^{31}$ DELGADO, Mario Luiz; FIGUEIREDO, Jones (Coord.), op. cit. p. 483-510.

${ }^{32}$ www.espacovital.com.br. Acesso em agosto de 2004.

${ }^{33}$ Íntegra do acórdão em www.tj.rs.gov.br. Acesso em agosto de 2004.
} 
tonio Vilenilson, julgado, por votação unânime, em 10.5.2005. O acórdão invoca o efeito imediato da lei que não se confunde com efeito retroativo, dando-me a honra de citar meus Comentários ao Código Civil. Direito de Família. Artigos 1.591 a 1.710, Saraiva, 2004.

Outros acórdãos do Tribunal paulista perfilham a mesma tese: Apelação nº 345.700-4/6-00, Relator Desembargador Vico Mañas, j. 02.12.2004; do mesmo Relator, a Apelação no 344.672-4/0-00, j. 02.12.2004..$^{34}$

Também admite a aplicação imediata da mutabilidade a casamentos celebrados antes da vigência do Código Civil de 2002, acórdão lavrado no Recurso Especial nº 730.546, da $4^{\underline{a}}$ Câmara, Relator Ministro Jorge Scartezzini, julgado em 23.8.2005, votação unânime.

Embora me pareça que o melhor entendimento, o mais razoável e mais justo seja o que defende a incidência da regra da mutabilidade do regime de bens aos casamentos celebrados antes do advento do Código Civil de 2002, é necessário considerar que, no início de vigência do novo Código pode haver interpretação divergente, sendo previstas inúmeras dúvidas sobre a exata interpretacão dos diversos artigos.

Entender que a mutabilidade do regime de bens só alcança casamentos celebrados a partir de janeiro de 2003, importará difícil e oneroso caminho aos interessados para alcançar o objetivo da alteração: separação judicial e divórcio - ou divórcio direto, quando cabível - e novo casamento com escolha de outro regime de bens, ressalvadas, em regra, as hipóteses de regime obrigatório de separação de bens.

Embora argumentos jurídicos sólidos embasem a tese da possibilidade de alteração do regime de bens quanto aos casamentos celebra- dos na vigência do Código de 1916 e, por isso, com grande possibilidade nortearão a Jurisprudência, seria conveniente restabelecer a redação do artigo 2.250 do Anteprojeto de Código Civil, de 1972, para que cônjuges não sejam prejudicados com eventual entendimento contrário: "O regime de bens nos casamentos celebrados na vigência do Código Civil de 1916 é o por este estabelecido, mas se rege pelas disposições do presente Código".

Enquanto não sobrevier a alteração da lei, a Doutrina e a Jurisprudência servirão de bom norte para fundamentar o pedido dos interessados. Invoque-se, ainda, o Enunciado n 260 aprovado na III Jornada de Direito Civil, promovida pelo Centro de Estudos Judiciários da Justiça Federal, propõe: "arts. $1.639 \S 2^{\circ}$ e 2.039 - A alteração do regime de bens prevista no $\S 2^{\circ}$ do art. 1.639 do Código Civil também é permitida nos casamentos realizados na vigência da legislação anterior".

\section{4 - Alteração do regime de bens: requisitos}

Estabelecido que a possibilidade de alterar o regime de bens alcança casamentos celebrados antes do Código Civil de 2002, passo a examinar os requisitos legais, em análise crítica.

Dispõe o $\$ 2$ do artigo 1.639 do CC..$^{35}$

"2ํ́ admissível alteração do regime de bens, mediante autorização judicial em pedido motivado de ambos os cônjuges, apurada a procedência das razões invocadas e ressalvados os direitos de terceiros".

A mais importante inovação do regime geral de bens é a possibilidade de sua alteração, prevista no $\S 2$.

Deve-se fazer justiça a quem foi um dos primeiros defensores da tese que sustenta a pos-

\footnotetext{
${ }^{34}$ A ambas as Apelações foi negado provimento, tendo em vista a motivação insuficiente, embora o Relator reconheça, na Ap. 344.672-4/0-0, que, "não se deve exigir extremado rigor ou formalismo na exposição das razões do casal, o que poderia violar a garantia da intimidade (art. 5o, X da Constituição federal e art. 21 do Código Civil)".

${ }^{35}$ Art. 1.639. "É lícito aos nubentes, antes de celebrado o casamento, estipular, quanto aos seus bens, o que lhes aprouver".

$\S 1$ O O regime de bens entre os cônjuges começa a vigorar desde a data do casamento.

$\S 2^{\circ}$ É admissível alteração do regime de bens, mediante autorização judicial em pedido motivado de ambos os cônjuges, apurada a procedência das razões invocadas e ressalvados os direitos de terceiros.
} 
sibilidade de ser revogável o regime de bens: $\mathrm{Or}$ lando Gomes. Propôs no Anteprojeto de Código Civil, artigo 167:

"Alteração do regime matrimonial - ressalvados os direitos de terceiros, o regime de bens do casamento, exceto o de separação obrigatória, poderá ser modificado, em qualquer tempo, a requerimento dos cônjuges, havendo decisão judicial permissiva, que será transcrita no registro próprio". ${ }^{36}$

Em "A Reforma do Código Civil", defende o autor a necessidade de ser abolida a regra consagradora da imutabilidade do regime matrimonial, afirmando que, em casos excepcionais, deve ser permitida sua alteração, resguardados direitos de terceiros. Informa que, para proteção da família, o Projeto advoga adotar-se a regra segundo a qual poderá qualquer dos cônjuges requerer a separação de bens "se a desordem nos negócios do outro puser em risco os interesses da família". ${ }^{37}$

Aos que veriam nessas inovações inconvenientes rupturas com a tradição, Orlando Gomes responde que é preciso reconhecer com lealdade e determinação que o respeito à continuidade da tradição não deve ser levado ao extremo de se conservarem institutos ou preceitos desatualizados. ${ }^{38}$

Frise-se que a imutabilidade do regime de bens não era absoluta, conforme demonstrou José Luiz Gavião de Almeida, ${ }^{39}$ ao apontar inúmeras exce- ções ao princípio consagrado no artigo 230 do Código Civil de 1916, elencando, exemplificativamente:

a) artigo $7^{\text {o }} \S 5^{\text {}}$ da Lei de Introdução ao Código Civil - cuida de estrangeiros naturalizados brasileiros;

b) artigo 5오 § 3 da Lei 6.515 de 1977 (Lei do Divórcio) - trata da separação-remédio e da separação-falência;

c) artigo 3ำ da Lei 883/49 - estabelece a concorrência do cônjuge casado sob regime de separação de bens com filho extramatrimonial do de cujus;

d) artigo 1.603, III - vocação hereditária do cônjuge, independentemente do regime de bens, inclusive separação total de bens;

e) artigo $1.611 \S 1^{\text {o }}$ - usufruto vidual ou direito real de habitação;

f) testamento que beneficia cônjuge casado sob regime de separação de bens;

g) artigo 246 - bens reservados;

h) artigo 1.776 - partilha em vida;

i) patrimônio após execução contra marido cuja meeira defendeu sua meação;

j) artigo 261 - período que antecede a transcrição das convenções antenupciais, no qual não terão efeito contra terceiros.

Aplaudo o entendimento de Orlando Gomes

${ }^{36}$ GOMES, Orlando. Anteprojeto de Código Civil. Brasília: Imprensa Nacional, 1963.

37 . A Reforma do Código Civil. Universidade da Bahia, 1965, p. 45.

${ }_{38}$ Também defende a possibilidade de alteração do regime de bens, na constância do casamento, Débora Gozzo na monografia Pacto Antenupcial, Saraiva. Anota que os países que autorizam a mudança do regime na constância da sociedade conjugal utilizam-se de mecanismos, como o Poder Judiciário, para evitar prejuízo a terceiros. Enfatizando que a experiência desses países demonstra ser possível a alteração de regime de bens sem prejudicar terceiros, propõe que ela também seja adotada entre nós.

Concordo, ainda, com a autora, quando afirma que os nubentes, na sua grande maioria, se sentem constrangidos para discutir questões de cunho patrimonial antes do casamento. Essa inibição natural pode levar a escolhas erradas quanto ao regime pelos nubentes muitas vezes jovens e inexperientes.

A autora invoca o sempre lembrado Orlando Gomes para afirmar que não haveria necessidade de permitir-se uma total liberdade aos cônjuges para efetuarem esta mudança para se evitar abusos. $\mathrm{O}$ modelo proposto por Orlando Gomes parece correto a Débora Gozzo :

a) requerimento por ambos os cônjuges, não se admitindo alteração unilateral;

b) justificação do pedido, devendo o juiz verificar se a vontade foi manifestada livremente e se os motivos foram plausíveis;

c) resguardo do interesse de terceiros, pela publicidade da sentença no registro próprio , protegendo direito cujo título seja anterior ao registro em tela. Ressalve-se que Orlando Gomes admite a alteração unilateral na hipótese de risco para os interesses da família.

${ }^{39}$ ALMEIDA, José Luiz Gavião de. Regime matrimonial de bens. Estudo inédito a ser publicado, gentilmente cedido pelo autor, professor doutor da Faculdade de Direito da Universidade de São Paulo e juiz do II TACivil de S. Paulo. 
e acrescento a seus argumentos que também avalizo, os de João Baptista Villela, um dos maiores defensores da tese da revogabilidade do regime de bens em tempos atuais.

No ensaio Regime de bens no casamento. Revogabilidade e segurança de terceiros, o autor analisa as legislações que admitem a revogabilidade do regime de bens, os requisitos para tanto e a evolução deles, cada vez menos rígidos, caminhando em direção à vontade do casal, sem perder de vista o resguardo dos interesses de terceiros. ${ }^{40}$

Ao analisar o direito alemão, enfatiza que a alteração do regime é admitida, não tendo sido restringida pela Lei sobre o Direito de Casamento e de Família, de 14.6.1976, com vigência para $1^{\text {o }}$ de julho de 1977. Antes ou depois do casamento, as partes podem, quantas vezes quiserem, convencionar o que desejarem quanto aos bens inclusive reoptar por regime antes adotado e abandonado.

Entre os países que admitem a mutabilidade do regime, citem-se Suíça, Espanha - a partir das Leis 14, de 2 de maio de 1975 e Lei 11, de 13 de maio de 1981 - França, Itália, Costa Rica, Bélgica (Lei de 14 de julho de 1976). Anota, ainda, que, ao contrário da Suíça (ZGB artigo 181,2), França (artigo 1.397 do Código Civil e Lei 65-570, de 13 de julho de 1965), Bélgica (artigo 1.395 do Código Civil) e Itália (artigo 162 do Código Civil), não se exige a intervenção autorizativa ou homologatória de serviço de tutela, como na Suíça, ou do Poder Judiciário, como nos demais países.

Na República Federal da Alemanha é o marido e a mulher que decidem, por eles mesmos, sem necessidade de submeter o pedido ao Judiciário.

Analisando o direito alemão, acentua que não há menosprezo aos direitos de terceiros, invocando os $\S \S 1.408$ e 1.412 do BGB.

O primeiro afirma o princípio da liberdade da pactuação e, o segundo, os limites de sua eficácia quanto a terceiros.
Se o contrato foi levado a registro, presume-se o conhecimento de terceiros. Se não o foi, depende de prova o conhecimento por parte do terceiro interessado. Distingue-se o registro do contrato matrimonial em registro próprio, da inscrição no registro de imóveis. Só este goza de fé pública.

O artigo 1.317 do Código Civil espanhol, lembrado por Villela, parece-me suficiente para orientar a interpretação a ser aplicada também ao direito brasileiro: "A modificação do regime econômico matrimonial realizada durante o casamento não prejudicará, em qualquer caso, os direitos já adquiridos por terceiros".

Tem razão José Luís de los Mozos ao esclarecer que este artigo pretende afirmar a irretroatividade da alteração do regime, como tenho sustentado em muitas oportunidades, neste livro, em aulas e palestras. ${ }^{41}$

Se o medo do regime de bens que permita a revogabilidade ou mutabilidade na constância do casamento era a salvaguarda do direito de terceiros, vê-se que o regime brasileiro o protege. Seja pela irretroatividade da norma, seja pela ressalva expressa a este direito. $\mathrm{O}$ que não se poderia mais admitir era o total desprezo ao livre arbítrio do casal, às suas conveniências que só o cotidiano repleto de surpresas justifica.

O direito patrimonial da família, representado com maior expressividade pelo regime de bens, por ser a vertente na qual com maior vigor se expressa a natureza contratual do casamento, deve prestigiar cada vez mais a vontade dos cônjuges, permitindo que muitos casamentos não se desfaçam pela absoluta ou relativa inadequação da escolha do regime de bens.

Ao contrário do que supunha Clóvis Bevilaqua, no início do século passado, casamentos não são eternos e por tal motivo não deveria ser imutável o regime de bens. Para ele: "Casamento é um contrato pessoal e perpétuo. O regime dos bens durante ele

\footnotetext{
${ }^{40}$ VILLELA, João Baptista. Regime de bens no casamento. Revogabilidade e segurança de terceiros. In: Estudos de Direito Brasileiro e Alemão. Studien zum brasilianischen und deutschen recht. Porto Alegre: Faculdade de Direito da Universidade Federal do Rio Grande do Sul, 1985. p.123-33. (Coleção Direito Comparado I).

${ }^{41}$ J.B. Villela se refere à obra Comentários al Código Civil y Compilaciones Forales. t. 18. v.1, Madrid: Ver. Der. Priv., 1982, p. 96-7.
} 
deve ser estável, inalterável, para corresponder à perpetuidade e imutabilidade das relações pessoais, enquanto perdura a sociedade conjugal".

Há muito, no Direito brasileiro, o casamento não é perpétuo. Desde o advento da Lei do Divórcio, de dezembro de 1977, já muito tardia. A falta de lei não impediu casais de viverem em união sem casamento. Esse argumento nem me parece válido ao tempo em que foi promulgado o Código de 1916. Hoje, menos ainda, com respaldo nas estatísticas do IBGE.

Ao argumento no sentido de que um cônjuge pode pressionar o outro para a alteração, o próprio Código responde com a exigência de pedido por ambos os cônjuges, que será examinado pelo juiz. Há instrumentos jurídicos diversos para que um cônjuge se proteja em relação ao outro, não se esquecendo que o regime não é retroativo e nada impede a separação judicial com a partilha de bens.

Há mais argumentos favoráveis à possibilidade de mudança de regime de bens durante o casamento, para lhe amparar a continuidade, do que o contrário.

O testemunho de respeitável advogado paulista é mais um dos que se podem invocar quanto à existência de inúmeros casais que, na vigência do regime da imutabilidade, separaram-se e divorciaram-se diante da impossibilidade de mudança do regime de bens que afeta expressivamente o relacionamento do casal. ${ }^{42}$

Uma preocupação me tem sido uma constante: a motivação do pedido de ambos os cônjuges ao juiz.

Ao exigi-la, o Código invade a privacidade do casal, exigindo que se alegue, por exemplo, a prodigalidade de um, a falta de cuidado com o patrimônio da família, a falta de controle nos gastos. Todas essás alegações serão suficientes para embasar o pedido de alteração do regime de bens, mas também o serão para repercutir negativamente no relacionamento do casal.

Minha esperança é que juízes não exijam que os interessados desçam a minúcias a respeito do comportamento de cada um que motiva a mudança do regime. Seria um desrespeito ao direito à intimidade, resguardado tanto pela Constituição Federal (artigo 5ㅜ, inciso X) como pelo Código Civil (artigos 11 a 21 e especialmente, artigo 21).43

A vontade das partes deveria bastar e, por isso, o pedido não deveria ser justificado, baseando-se na conveniência do casal que nem precisaria ser mencionada. Como o $§ 2^{\circ}$ do artigo 1.639 alude a "apuradas a procedência das razões invocadas", devese motivar o pedido, interpretando-se, porém, o parágrafo em tela à luz da Constituição Federal que protege a intimidade e a vida privada das pessoas.

Com respaldo no direito à intimidade e à vida privada, direitos de personalidade, no meu modo de ver, basta que o casal alegue conveniência das partes embasada na experiência da vida em comum.

No futuro, espero que este parágrafo seja modificado para permitir a livre mudança do regime de bens, por consenso de ambas as partes, sem necessidade de motivação, resguardados direitos de terceiros.

A apreciação pelo juiz será sempre possível, em casos não expressamente agasalhados pelo Código Civil ou que possam suscitar fundada dúvida pelos interessados ou pelo Registro Civil - como, por exemplo, a possibilidade de mudar o regime de bens aos casados com inobservância das causas suspensivas previstas no artigo 1.523 do Código Civil considerando-se o princípio da inafastabilidade da tutela jurisdicional consagrada no inciso XXXV do artigo $5^{\circ}$ da Constituição Federal, segundo o qual "a lei não exchirá da apreciação do Poder Judiciário lesão ou ameaça a direito".

${ }^{42}$ Consulte-se de José de Castro Bigi, O regime de bens no atual Código e no Projeto. In: Direito de Família. Revista do Advogado, Associação dos Advogados de São Paulo, n.25, maio 88, p. 70-5. A afirmação, baseada na experiência profissional do autor, encontra-se na página 71.

${ }^{43}$ Não me é desconhecida a diferença entre vida privada, intimidade (ou privacidade, ou privatividade) e segredo. A vida privada é um círculo maior que contém a intimidade e o segredo. Confronte-se, por todos, Paulo José da Costa Júnior in $\mathrm{O}$ direito de estar só. Tutela penal da intimidade. 2.ed. Revista dos Tribunais, São Paulo, 1995. 
REFERÊNCIAS BIBLIOGRÁFICAS

AZEVEDO, Álvaro Villaçá. Contrato de Casamento, sua extinção e renúncia de alimentos na separação consensual. In: Estudos em homenagem a Washington de Barros Monteiro. São Paulo: Saraiva, 1982.

BEVILAQUA, Clóvis. Direito de Família. 5.ed. Rio de Janeiro: Freitas Bastos, 1933.

BIGI, José de Castro. O regime de bens no atual Código e no Projeto. In: Direito de Família. Revista do Advogado. Associação dos Advogados de São Paulo, n.25, p. 70-5. maio 88.

CHINELATO, Silmara Juny. Comentários ao Código Civil. Parte Especial. Direito de Família. Arts. 1.591-1.710. Antonio Junqueira de Azevedo (Coord.). São Paulo: Saraiva, 2004. v. 18.

COSTA JR, Paulo José. O direito de estar só. Tutela penal da intimidade. 2.ed. São Paulo. Revista dos Tribunais, 1995.

DELGADO, Mário Luiz; FIGUEIREDO, Jones (Coord.). Problemas de direito intertemporal: breves considerações sobre as disposições finais e transitórias do novo Código Civil brasileiro. In: Novo Código Civil. Questões controvertidas. São Paulo: Métodos, 2003. p. 483-510.

ESPÍNOLA, Eduardo. A Família no Direito Civil brasileiro. Rio de Janeiro: Gazeta Judiciária, 1957. n.12.

GAVIÃO DE ALMEIDA, José Luiz. Regime matrimonial de bens. Artigo inédito.

GANGI, Calogero. Il Matrimonio. 3.ed. Milano: Giuffrè-Editore, 1953.

GIORDANI, Mário Curtis. O Código civil à luz do Direito Romano. Direito de Família. Rio de Janeiro: Lumen Juris, 1996.

GOMES, Orlando. Direito de Família. 11.ed. (Atualizada por Humberto Teodoro Júnior). Rio de Janeiro: Forense, 1999.

. Anteprojeto de Código Civil. Imprensa Nacional, 1963.

GOZZO, Débora. Pacto antenupcial. São Paulo: Saraiva: 1992.

FRANÇA, Rubens Limongi. Do matrimônio como fato jurídico. Revista dos Tribunais, São Paulo, 389:21, n.6.

. Manual de Direito Civil. São Paulo: Revista dos Tribunais, v. 2, tomo 1, 1972.

. Direito Intertemporal Brasileiro: doutrina da irretroatividade das leis e do direito adquirido. 2.ed. São Paulo: Revista dos Tribunais, 1968.

. A irretroatividade das leis e o direito adquirido. 6. ed. São Paulo: Saraiva, 2000.

. Jurisprudência da irretroatividade e do direito adquirido. São Paulo: Revista dos Tribunais, 1982.

MONTEIRO, Washington de Barros. Curso de Direito Civil: Direito de Família. 36.ed. São Paulo: Saraiva, 2001. v.2.

OLIVEIRA, Euclides de. Alteração do regime de bens no casamento. In: Novo Código Civil. Questões controvertidas. Mario Luiz

Delgado; Jones Fígueiredo, (Coord.). São Paulo: Métodos, 2003, p. 389-404.

OLIVEIRA, José Lamartine Correa de; MUNIZ, Francisco. Curso de Direito de Família. 3. ed. Curitiba: Juruá, 1999.

PEREIRA, Lafayette Rodrigues. Direitos de Família. Anotações e adaptações ao Código Civil por José Bonifácio de Andrada e Silva. Rio de Janeiro: Virgilio Maia, 1918.

PEREIRA, Caio Mário da Silva. Instituições de Direito Civil. Direito de Família. 11.ed. Rio de Janeiro: Forense, 1999. v. 5.

PONTES DE MIRANDA, Francisco Cavalcanti. Tratado de Direito de Família. Direito matrimonial. São Paulo: Max Limonad,

1947. v. 2.

RODRIGUES, Silvio. Direito civil. Direito de Família. 27.ed. São Paulo: Saraiva, 2002, p. 19.

SANTO, Luiz Felipe Brasil. A mutabilidade dos regimes de bens. Disponível em $<$ www.migalhas.com.br/todos $>$ os autores/todos os artigos <www.ibdfam.com.br>> Acesso em agosto de 2004.

TERRÉ, François; SIMLER, Philippe. Les régimes matrimoniaux. 3.ed. Paris: Dalloz, 2001.

VILLELA, João Baptista. Regime de bens no casamento. Revogabilidade e segurança de terceiros. In: Estudos de Direito Brasileiro e Alemão. Studien zum brasilianischen und deutschen recht. Porto Alegre: Faculdade de Direito da Universidade Federal do Rio Grande do Sul, 1985. p.123-33. (Coleção Direito Comparado I). 